\title{
RETENSI MODAL PENGETAHUAN DAN SUMBERDAYA INTERNAL PERUSAHAAN
}

\author{
Agustian Budi Prasetya \\ Binus Business School, Universitas Bina Nusantara \\ agustian.prasetya@binus.ac.id
}

\begin{abstract}
The paper discuss about retention model of corporate knowledge capital and identification internal resources that affect the efectivity of retention of corporate knowledge capital. The research utilize desk research methodes, based on academic literaturs. The paper describe analytically the DeLong and Arif et.all of knowedge retention model, apply with retention cases. The paper found that along with effort to keep the corporate capital knowledge, company might face threat of loosing the knowledge, the capacity to make decision effectively due to the mismanagement of company internal resurces, such as: staffing, turnover, recruitment, eangement to type of short term project; weak leadership and prioritizing; ineffective of information technology management.
\end{abstract}

Key words : knowledge retention, corporate knowledge capital, company internal resources, loss of knowledge

\section{PENDAHULUAN}

Di era ekonomi yang mengutamakan
modal pengetahuan untuk pertumbuhan ekonomi, perusahaan juga mengutamakan modal pengetahuan sebagai asset utama perusahaan agar usaha tetap bertahan secara kompetitif. Modal pengetahuan di perusahaan melekat pada kapasitas bertindak karyawan untuk memajukan perusahaan. Kemampuan teknologi informasi untuk mengolah data dan sumber akses informasi, juga menyumbang kapasitas karyawan untuk belajar dan beinovasi agar sebuah perusahaan memiliki posisi stategis di masyarakat (Farrukh.2015). Beberapa literature membahas modal pengetahuan sebagai tipe pengetahuan pada tingkat individual, kolektif dan organisasional ( DeLong: 2004),(Muhammed Arif. et. ll.,2012). Nonaka membahas modal pengetahuan sebagai pengetahuan eksplisit atau tasit yang melekat di dalam kemampuan karyawan. Pengetahuan eksplisit biasanya terkodifikasi baik dalam peraturan formal, teknologi dan proses proses kerja yang nampak. Sementara pengetahuan tasit tidak mudah untuk dijelaskan secara deskriptif, namun melekat pada individu.Melalui proses interaksi dan konversi, pengetahuan tasit dan eksplisit individu karyawan menjadi pengetahuan organisasional yang digunakan sebagai sumber inovasi (Nonaka, Ryko, Toyama .2001). Blankenship, et.all (2007) juga memperkuat pandangan Nonaka mengenai tipe pengetahuan tasit dan eksplisit dan menambahkan pemahaman mengenai tipe eksposur dari pengetahuan tersebut untuk pihak lain.

Mencermati pembahasan mengenai modal pengetahuan di perusahaan, Delong (2004), Denner dan Diaz (2011), Muhammed 
Arif (2012) menyebutkan tantangan dalam pengelolaan modal pengetahuan di perusahaan adalah menjaga (retain) agar modal pengetahuan tetap berada di perusahaan meskipun sumberdaya manusia keluar dari perusahaan. DeLong menyebut sebagai upaya retensi pengetahuan di perusahaan. Mengingat pengetahuan melekat kepada individu, sehingga kehilangan karyawan ( misalnya pensiun, mutasi), perusahaan memerlukan upaya untuk mencegah modal pengetahuan perusahaan dibawa keluar oleh karyawan. DeLong mengidentifikasi akibat yang dihadapi perusahaan ketika modal pengetahuan perusahaan hilang, bersamaan dengan karyawan keluar dari perusahaan. Perusahaan akan terhambat kelancaran kegiatan operasi rutinnya, beberapa pekerjaan tertunda urutannya, kapasitas inovasi berkurang, pilihan strategi akan terhambat, efisiensi perusahaan tidak optimal, dan kesemuanya berujung kepada ketidakmampuan perusahaan tetap kompetitif dibandingkan pesaing. ( 2004: 31) Berdasarkan latar belakang pentingnya retensi modal pengetahuan bagi perusahaan, paper ini membahas retensi modal pengetahuan di perusahaan dengan menjawab pertanyaan : Apa tahapan mengelola retensi modal pengetahuan di perusahaan? Apa sumberdaya internal di perusahaan yang perlu diperhatikan untuk mengelola tahapan retensi modal pengetahuan di perusahaan?

\section{METODE}

Untuk menjawab permasalah penulisan, digunakan studi kepustakaan untuk mengkaji tahapan pengelolaan retensi modal pengetahuan. Paper ini juga akan mengkaji dan menjelaskan secara deskriptis analisis berdasarkan kepustakaan terbitan luar negeri maupun dalam negeri, untuk menjelaskan sumberdaya internal perusahaan yang diperlukan untuk mengelola retensi modal pengetahuan di perusahaan. Berdasarkan tinjauan kepustakaan,paper ini mengelaborasi kajian Petrides (2003), DeLong (2004) mengenai sumber sumber internal di perusahaan dalam hubungannya dengan pengelolaan retensi modal pengetahuan. Analisis juga dilengkapi dengan kajian penelitian retensi modal pengetahuan di Jakarta (Irsan.2012) dan di Zambia, Afrika Selatan (Wamundila.2011). Menganalisis model pengelolaan retensi modal pengetahuan untuk menjawab pertanyaan penelitian, paper ini menganalisis kajian Mohammed Arif et.all (2012), dilengkapi dengan analisis tipe tipe pengetahuan dari Blankenship (2007), DeLong(2004) dan Nonaka (2001) untuk menjelaskan secara deskriptis analitis tahapan pengelolaan retensi pengetahuan.

\section{HASIL KAJIAN DAN PEMBAHASAN}

Kajian mengenai pengelolaan retensi modal pengetahuan di perusahaan dilakukan berdasarkan pemahaman mengenai tipe pengetahuan dan modal pengetahuan yang melekat pada diri manusia atau karyawan perusahaan. DeLong (2004) menyebutkan pengelolaan retensi modal pengetahuan adalah mengelola alur pengetahuan (flow of knowledge) di perusahaan yang tersedia digunakan ketika dibutuhkan. Ketiadaan pengetahuan ketika perusahaan membutuhkan, perusahaan akan membuat keputusan yang tidak efektif dan mengurangi kapasitas pemenuhan kebutuhan perusahaan. (DeLong, 2004, p.21). Denner dan Diaz (2011), menjelaskan retensi modal pengetahuan di perusahaan sebagai aktivitas menyimpan pengetahuan dan memanggil (retrieve) pengetahuan dari tempat penyimpanan untuk 
digunakan. Pengetahuan yang dipanggil dapat bersumber dari individu karyawan maupun pengetahuan di perusahaan yang telah teridentifikasi filling sistem nya, terorganisir cara penggunaannya, terpelihara kebaruannya oleh perusahaan. Muhammed Arif (2012) merujuk pengelolaan retensi modal pengetahuan sebagui upaya formal perusahaan mengelaborasi, mengekstrak, menyimpan dan memanggil pengetahuan di perusahaan. Sehingga pengetahuan yang tersedia tersebut digunakan sebagai dasar pembuatan keputusan di perusahaan. Dari beberapa kajian mengenai pengelolaan retensi modal pengetahuan dapat disampaikan bahwa upaya retensi modal pengetahuan di perusahaan merujuk kepada upaya perusahaan mengelola data dan informasi yang berasal dari aktivitas individu, kelompok karyawan di perusahaan. Data dan informasi ini secara formal digunakan untuk dasar pembuatan keputusan, kebijakan di perusahaan atau dasar aktivitas pemenuhan kebutuhan pemangku kepentingan oleh perusahaan. Data di perusahaan dapat berbentuk angka,fakta. Data di perusahaan belum memiliki intepretasi atau makna khusus. Masih berupa angka, image, figur tanpa konteks organisasional. Misalnya Worksheets in spreadsheets yang disajikan tanpa analisis atau interepretasi merupakan data. Data menjadi informasi yang berguna di perusahaan ketika data telah di kelompokkan menjadi pola tertentu, kategorisasi tertentu, dianalisis, dipaparkan melalui berbagai komunikasi, dan bermakna kontekstual bagi pihak pihak di perusahaan. Informasi, bukan data, yang mempengaruhi persepsi, justifikasi dan perilaku dan keputusan keputusan penting di perusahaan.

DeLong membahas modal pengetahuan dengan menggarisbawahi bahwa modal pengetahuan terakumulasi dari data, informasi dan interaksi sumberdaya manusia di dalam dan di luar perusahaan. Oleh karena itu modal pengetahuan perusahaan perlu di jaga seiring dengan kemungkinan sumberdaya manusia berhenti bekerja di perusahaan. DeLong mengidentifikasi tipe-tipe pengetahuan, yaitu : pengetahuan individual karyawan di perusahaan ( human knowledge), pengetahuan sosial (social knowledge), pengetahuan budaya (cultural knowledge), dan pengetahuan structural (structured knowledge). Human knowledge merujuk kepada apa dan bagaimana individu karyawan bekerja, keterampilan karyawan dalam menjalankan tugas operasional perusahaan seperti tugas di bagian keuangan, marketing, atau administrasi pendidikan dan menjalankan tugas mengajar misalnya . Human knowledge ini biasanya modal pengetahuan tasit dan eksplisit yang melekat di diri karyawan sebagaimana dirujuk oleh Nonaka (2001), atau Blankenship (2007). Social knowledge adalah modal pengetahuan untuk mengelola hubungan atau relasi antar individu di dalam kelompok di perusahaan. Cultural knowledge : modal pengetahuan yang terefleksi di dalam perilaku perilaku konformitas karyawan terhadap nilai nilai perusahaan. Sementara structured knowledge atau pengetahuan struktural adalah modal pengetahuan yang dimiliki perusahaan dalam bentuk sistem kerja, proses pelaksanaan kerja , perangkat kerja untuk menyediakan jasa atau produk, termasuk modal struktural adalah routine kegiatan yang diukur kinerjanya oleh perusahaan. Berbagai tipe modal pengetahuan di perusahaan akan memiliki nilai tambah khususnya ketika aktivitas karyawan di perusahaan ditunjang oleh teknologi komunikasi dan informasi. Karyawan mudah mendapatkan akses berbagi data, informasi dan pengetahuan di dalam dan dari ke luar perusahaan. Hal ini mengingat konsepsi modal 
pengetahuan di perusahaan seringkali merujuk kepada kesatuan fakta-fakta yang terakumulasi dialam kehidupan di perusahaan dalam suatu waktu.

Tipe tipe modal pengetahuan di dalam perusahaan itu dapat hilang utamanya ketika sumberdaya manusia yang memiliki posisi penting di perusahaan. Modal pengetahuan juga hilang ketika sistem dan prosedur, misalnya di Human Resourcess Development, tidak memadai lagi. Data-data dan informasi mengenai HRD tidak diperbaharui, standar operasi rekrutmen tidak terdokumentasi dengan baik. Hal ini akan mempengaruhi kualitas rekrutmen bagian HRD. Dengan demikian pembuatan keputusan di HRD atau kapasitas bertindak bagian HRD akan tidak efektif karena hilangnya salah satu modal pengetahuan di bagian HRD. Modal pengetahuan struktural, dapat hilang karena ketidakcakapan tenaga kerja yang diharapkan untuk memberikan layanan prima kepada pelanggan, meskipun terdapat standard dan prosedur layanan. Demikian pula modal pengetahuan struktural dapat hilang ketika efektifitas pelatihan misalnya tidak optimal, sehingga hasil pelatihan untuk meningkatkan pelayanan perusahaan kepada pelanggan tidak dapat memenuhi ekspektasi. Dari ilustrasi tipe tipe modal pengetahuan di perusahaan dan akibat yang ditimbulkan ketika modal pengetahuan hilang, dapat disampaikan bahwa modal pengetahuan di perusahaan melekat pada diri individual dan pada tingkat kolektif karyawan, modal pengetahuan juga melekat di dalam routine atau proses kerja di perusahaan. Oleh karena itu, mengelola retensi modal pengetahuan di perusahaan menekankan kemampuan perusahaan menggunakan data dan informasi, melalui memprosesan data, pengumpulan dan menyebarkan informasi kepada pihak di dalam dan di luar perusahaan perusahaan. Data dan informasi dari dan kedalam perusahaan merupakan dasar pembentukan modal pengetahuan yang pada gilirannya modal pengetahuan yang terjaga akan membedakan satu perusahaan dengan perusahaan yang lain, dan juga akan mendorong perusahaan mencapai tujuannya dengan lebih baik. Kehilangan modal pengetahuan oleh karena itu berkurang efektivitas pembuatan keputusan untuk mencapai tujuan perusahaan. Oleh karena itu di paper ini dapat diargumentasikan bahwa tanpa data dan informasi, perusahaan tidak dapat menghasilkan pengetahuan. Di kajiannya DeLong juga menyampaikan tipe tipe modal pengetahuan di perusahaan berkembang seiring dengan aktivitas transfer informasi dan data di antara karyawan, dan pertukaran data di dalam dan luar perusahaan. Transfer pengetahuan utamanya diperlukan dilakukan oleh sumberdaya manusia di perusahaan yang menduduki posisi penting untuk kelangsungan bisnis; sehingga bilamana pihak tersebut keluar dari perusahaan atau pensiun, perusahaan tidak kehilangan pengetahuan. Kegiatan asesmen untuk mengidentifikasi modal pengetahuan yang bersumber dari posisi posisi penting di perusahaan berguna untuk mengelola transfer modal pengetahuan. Sehingga bilamana sumberdaya yang dimaksud keluar dari perusahaan, telah dilakukan upaya transfer modal pengetahuan, melalui kegiatan sehari-hari di perusahaan. Modal pengetahuan perusahaan dengan demikian juga dipahami sebagai pengetahuan yang melekat di dalam individu, namun kemudian dapat dilakukan transfer pengetahuan, dipelajari dan diperbaharui. Misalnya modal pengetahuan di lembaga pendidikan, menurut Hautala ( 2011) diciptakan melalui proses transfer data dan informasi akademik, disertai dengan interaksi, diskusi, pertemuan fisik orang perorang 
maupun kolektif. Kemudian data dan informasi itu digunakan untuk menghasilkan penulisan materi ajar dan penelitian. Oleh karena itu modal pengetahuan perusahaan merupakan data dan informasi yang telah dikelompokkan, dipahami oleh penggunanya, memiliki konteks pengalaman baik pada tingkat individu maupun kelompok. Lebih dari itu data dan informasi itu diterapkan untuk membuat sebuah keputusan, menjadi inisitiatif manajemen, digunakan sebagai bagian kegiatan rutin, dapat dipelajari dan di transger secara informal ataupun proses pelatihan formal di perusahaan. di Inggris, Amerika dan Australia menjelaskan bahwa upaya retensi modal pengetahuan perusahaan tidak terlepas dari upaya kreasi pengetahuan, akuisisi atau pemerolehan pengetahuan, transfer pengetahuan, penyimpanan pengetahuan. Arif menjelaskan mengelola retensi modal pengetahuan perusahaan dalam 4 tahapan. Arif menggunakan teori Nonaka dan Takeuci mengenai SECI model, dan teori Walsh and Ungson mengenai memori organisasional.

Muhammed Arif et. all. (2012) bekerjasama dengan beberapa peneliti dari perguruan tinggi

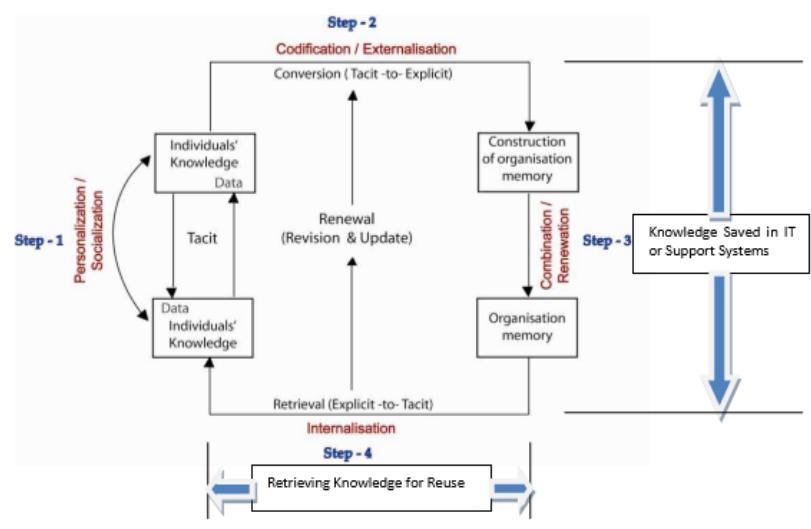

Figure 1 The Knowledge Retention Mode

Dijelaskan Arif, dalam figure 1, the Knowledge Retension Model, dasar tahapan retensi modal pengetahuan di perusahaan adalah peranan individu karyawan perusahaan dalam mengakuisisi pengetahuan, menyimpan dan memanggil (retrieve) pengetahuan yang dimilikinya. Tahap pertama dari model retensi ini adalah pengetahuan individual karyawan (human knowledge), sosialisasi, berbagai data dan informasi yang dimiliki kepada karyawan lain. Individu karyawan saling berbagi human knowledgenya sebagai upaya menyempurnakan aktivitas sehari hari, atau meningkatkan kinerja perusahaan. Tahap kedua dalam pengelolaan retensi modal pengetahuan perusahaan adalah penggunaan human knowledge, dikonversi menjadi dokumen kegiatan sehari hari, dan digunakan sebagai referensi unit, departemen atau bagian perusahaan; sehingga perusahaan dapat meningkatkan pembuatan keputusan atau efektivitas pelaksanaan kebijakan di perusahaan. Meskipun demikian, menurut Muhammed Arif, retensi modal pengetahuan individu atau human knowledge yang telah terkonversi sebagai dokumen-dokumen 
kegiatan, masih perlu ditingkatkan di tahap tiga ketika dokument dokumen ini kemudian telah menjadi bagian dari konstruksi teknologi penyimpanan yang dapat digunakan secara kolektif untuk membuat keputusan. Kontruksi teknologi penyimpanan kolektif ini paling sederhana berbentuk manual atau prosedur. Di tahap ke empat pengelolaan retensi modal pengetahuan perusahaan, menurut Muhammed Arif, diperlukan proses internalisasi dari pengetahuan yang telah tersimpan di dalam teknologi penyimpanan, yaitu : terinternalisasi dalam rutin kegiatankegiatan rutin kembali. Modal pengetahuan yang tersimpan di teknologi penyimpanan di perusahaan, di tahap ke empat juga harus mudah di panggil, diunduh, dikembangkan secara individu per individual atau kelompok karyawan guna disesuaian kembali relevansinya untuk kegiatan kegiatan mendatang perusahaan yang lebih maju .

Bila Arif menyebutkan 4 tahapan upaya retensi modal pengetahuan di perusahaan, DeLong (2004) menyebutkan 3 aktivitas utama dalam untuk mengelola retensi modal pengetahuan. Aktivitas itu adalah knowledge acquisition, knowledge storage, knowledge retrieval. Knowledge acquisition atau pememperolehan pengetahuan adalah aktivitas praktek kerja, aktivitas kerja bersama, rutinitas pelayanan sehari hari namun berorientasi ke depan. Pemerolehan pengetahuan ini, misalnya juga dapat dalam bentuk pelatihan atau mentoring , bekerjasama menyelesaikan kewajiban untuk pemangku kepentingan seperti, pemerintah juga bagian dari pemeroleh pengetahuan di perusahaan. Knowledge storage adalah upaya organisasional untuk menyimpan pengetahuan di dalam organisasi agar dapat digunakan sewaktu waktu ketika diperlukan. Pengetahuan yang disimpan baik dalam bentuk manual, ataupun penyimpanan pengetahuan ini difasilitas oleh teknologi. Knowledge retrieval, tahapan ketiga upaya retensi modal pengetahuan, adalah aktivitas rutin untuk mengakses dan menggunakan informasi bersama. Dalam perpesktif retensi modal pengetahuan dari DeLong, elemen-elemen yang dapat diamati di dalam perusahaan adalah praktik dan proses kerja sumberdaya manusia sehari hari, infrastruktur kerja, pola pola kerja untuk mengimplementasikan strategi, transfer pengetahuan untuk meningkatkan kinerja perusahaan, dan sistem penyimpanan data dan informasi berbasi teknologi yang mudah diterima, mudah diimplementasikan, dan mudah dijalankan secara bersama.

Kajian DeLong diterapkan oleh Wamundila (2011), untuk meneliti pengelolaan retensi modal pengetahuan perguruan tinggi di Zambia. Wamundila mengindentifikasi upaya retensi modal pengetahuan di lembaga pendidikan sebagaimana dikemukakan oleh DeLong. Upaya yang diamati oleh Wamundila adalah aktivitas asesmen sumber-sumber pengetahuan, kegiatan akuisisi atau pemerolehan pengetahuan, dan transfer pengetahuan. Berdasarkan penelitian DeLong dan Wamundila, juga dilakukan Irvan et.all (2012) untuk melihat retensi modal pengetahuan perusahaan multinasional penyedia jasaboga berbasis di Jakarta. Hasil yang didapat dari penelitian Wamundila dan Irvan mengenai retensi modal pengetahuan disampaikan : asesmen sumber-sumber pengetahuan harus menunjukkan inventori kompetensi dan kecakapan sumberdaya manusianya. Sementara kajian Irvan et.all asesmen sumber sumber pengetahuan, harus mengidentifikasi sumber pengetahuan yang paling penting di dalam rantai kegiatan perusahaan dan upaya upaya transfer 
pengetahuan agar perusahaan dapat menjaga modal pengetahuan yang bersumber dari aktivitas terpenting di dalam rantai usaha. Wamundila juga mendeskripsikan di kegiatan asesmen untuk identifikasi sejauh mana pengetahuan eksplisit telah ter ekspos dengan baik di perusahaan, sejauh mana mudah terakses, diunduh dan out of date relevansi nya. Asesmen juga mengidentifikasi ada tidaknya panduan, kebijakan, manual kerja,prosedur yang mencukupi untuk menjalankan proyek bersama. Asesmen mengenai kinerja untuk mengindentifikasi ekspektasi kinerja seperti pihak yang dibawah ekspektasi atau melebihi ekspektasi.

Pemerolehan pengetahuan atau akuisisi pengetahuan, sebagai bagian dari upaya retensi modal pengetahuan, menurut DeLong dilakukan dengan berdasarkan perencanaan kerja, rencana pengembangan serta ketersediaan inventori keterampilan tenaga kerja. Termasuk di dalam pemerolehan pengetahuan adalah aktivitas rekruitmen yang relevan dengan perencanaan kerja, pelatihan dan pengembangan yang sesuai dengan kebutuhan, menyediakan infrastruktur untuk diskusi terbuka mencari pemecahan baru, merancang transfer untuk keahlian berbasis kelompok, mengelola jaringan nara sumber keahlian dan review atau monitoring senyata (riil time) pekerjaan dilakukan sehari hari. Akuisisi pengetahuan ini diperlukan untuk memastikan modal pengetahuan terjaga dan perusahaan dapat melakukan akuisisi secara berkesinambungan. Selain kegiatan pemerolehan pengetahuan tersebut, Wimundila, Irvan juga menyampaikan aktivitas transfer pengetahuan untuk menjaga retensi modal pengetahuan perusahaan berdasarkan penelitian di Zambia dan Jakarta. Disebutkan antara lain aktivitas transfer pengetahuan dengan membentuk komunitas para ahli, termasuk perencanaan untuk membentuk kelompok mentor, coaching, rotasi pekerjaan atau berbagai cara untuk transfer pengetahuan. Kegiatan transfer pengetahuan melalui kelompok komunitas dapat menjadi aktivitas utama transfer pengetahuan. Mengingat kelompok komunitas ini dibentuk karena adanya "sense of community" dan ikatan sosial emosional di dalam komunitas (Nistor et.all.,2015). Beberapa kegiatan transfer pengetahuan yang lain: kegiatan suatu proyek pekerjaan yang dilakukan bersama, aktivitas mengidentifikasi problem operasional berikut solusi yang terukur. Transfer pengetahuan, dalam laporan penelitian Wamundila juga diidentifikasi bentuk kerjasama karyawan dan staf akademik untuk menciptakan kebaruan manual dan regulasi seiring dengan tugas yang ditangani. Menangani kebaruan manual misalnya diupayakan sebagai cara mengantisipasi skala pekerjaan yang lebih besar di kedepannya. Termasuk dalam upaya retensi modal pengetahuan perusahaan melalui kegiatan transfer pengetahuan adalah menjalankan kegiatan rutin namun dilakukan bersama-sama dan secara berbeda. Dari paparan hasil kajian kepustakaan mengenai tipe tipe pengetahuan dan tahapan retensi pengetahuan dari Arif dan DeLong, dapat disimpulkan peranan sumberdaya manusia untuk menghasilkan modal pengetahuan perusahaan, upaya interaksi melalui sosialisasi, internalisasi pengetahuan dan transfer pengetahuan, serta proses retensi modal pengetahuan yang perlu menyertakan teknologi komunikasi dan penyimpanan, asesmen dan pemerolehan pengetahuan

Paper ini juga membahas sumberdaya internal perusahaan yang seringkali 
menghambat upaya retensi modal pengetahuan di perusahaan. Berdasarkan penelitian Petrides (2003), Wimundila (2011), Irvan et.all (2012) , di paper diidentifikasi tiga sumberdaya internal perusahaan, yaitu : pertama kekurangan staf karena karyawan keluar (turnover) atau proses mis-rekruitmen, kedua kepemimpinan yang lemah dalam pengembangan prioritas. Ketiga, pengembangan teknologi informasi yang tidak efektif seperti inkompatibilititas perangkat lunak, kualitas buruk data dan pengolahannya. Turnover, kualitas, pekerjaan berjangka pendek,adalah sumber ancaman retensi modal pengetahuan perusahaan. Proyek jangka pendek atau pekerjaan yang tidak relevan dengan pengembangan keahlian di perusahaan, lokasi proyek yang jauh dari kantor pusat , kesemuanya dapat disebut membuka ancaman terhadap retainmen modal pengetahuan perusahaan. Pekerjaan jangka pendek seringkali tidak kontekstual dengan usaha, dan tidak memberikan nilai tambah terhadap bisnis inti (core business) misalnya: perusahaan tidak mendapat nilai tambah pengetahuan dari proyek, keanggotaan team yang bersifat adhoc, atau temporer dan dan membuka peluang inkompeten anggota team bergabung. Informasi, data pekerjaan yang dilakukan tidak memberi nilai tambah terhadap pengembangan prosedur kerjayang ada di perusahaan. Fenomena turnover dan kegiatan proyek berjangka pendek yang kurang relevan dengan upaya membangun retensi modal pengetahuan diteliti oleh Tong-Ming Lim et.all (2013) di Malaysia. Penelitian menggarisbawahi bahwa pengelolaan pekerjaan yang bersifat jangka pendek, seringkali tidak memberikan lessons learned, mengingat tidak mendapat konteks visi perusahaan dan dukungan pemimpin. Sehingga anggota team tidak melakukan transfer pengetahuan menjadi modal pengetahuan bagi perusahaan. Keanggotaan team kerja di dalam proyek jangka pendek seringkali juga bekerja secara parsial, sehingga anggota team tersebut memiliki keterbatasan konteks dalam pengerjaan tugas tugas yang seharusnya diproyeksikan memiliki konteks jangka panjang dan penciptaan modal pengetahuan di perusahaan. Dalam bahasan Asderaki dan Samul (2015), turnover, rekrut sumber daya di dalam proyek jangka pendek dan anggota staf lepasan (part time), tidak mendapat kesempatan untuk mengembangkan pemerolehan pengetahuan di perusahaan. Sementara, disebutkan Asderaki bahwa kesempatan berbagi dalam kerja dengan sesama karyawan, akan meningkatkan ekspektasi pemerolehan pengetahuan dan kesempatan berbagi pengetahuan juga. Dengan demikian dapat disimpulkan ancaman kehilangan modal pengetahuan dari sumberdaya internal ketika didapati terjadi kualitas alur berbagi pengetahuan tidak berkualitas. Termasuk ancaman kehilangan modal pengetahuan ketika transfer pengetahuan melalui pelatihan tidak dapat berjalan. Pelatihan adalah meningkatkan stok pengetahuan sumberdaya manusia. Ketika pelatihan tidak efektif, stok pengetahuan tidak meningkat. Sehingga alur berbagi pengetahahuan, flow of knowledge, melalui kerjasama tugas selepas pelatihan, tidak efektif : tidak menjadi peningkatan kecakapan sumberdaya manusia bagi perusahaan.

Selain turn over karyawan dan tipe pekerjaan, sumberdaya internal yang dapat mengancam retensi pengetahuan adalah kepemimpinan yang lemah (weak leadership) di perusahaan. Khususnya, kecakapan pemimpin dalam mengelola prioritas yang mempengaruhi kerjasama diantara staf atau karyawan perusahaan, mengontrol dan fokus kepada 
tujuan tujuan perusahaan. Kepemimpinan yang tidak dibangun atas dasar merit sistem, pengalaman, kualifikasi, dan keluasan jejaring untuk bisnis perusahaan, juga dapat menjadi sumberdaya penghambat modal pengetahuan perusahaan. Tugas dan fungsi kepemimpinan salah satunya adalah membawa visi perusahaan. Sehingga memberikan konteks terhadap berbagai data, informasi bagi karyawan di bawah area otoritasnya, untuk kepentingan pencapaian visi adalah sangat kritikal dalam bangunan retensi modal pengetahuan perusahaan. Beberapa indikasi dari kepemimpinan dan potensi kehilangan modal pengetahuan adalah alur pengetahuan tidak beranjak dari masing masing bagian. Sehingga proses sosialisasi, internalisasi pengetahuan tasit dan eksplisit pada tingkat individual karyawan tidak menjadi modal pengatahuan perusahaan. Kepemimpinan mempengaruhi bagaimana situasi yang memungkinkan terjadinya komunikasi di dalam organisasi, sehingga data dan informasi yang tersedia, dapat menyumbang solusi atau meningkatkan kualitas pembuatan keputusan di dalam organisasi. Kepemimpinan juga merupakan faktor penting dalam retensi modal pengetahuan perusahaan, khususnya dalam hal pemimpin mengindentifikasi pengetahuan yang penting yang untuk organisasi untuk meningkatkan kinerja perusahaan secara keseluruhan. Bahasan mengenai kepemimpinan dan retensi pengetahuan modal pengetahuan dibahas oleh Lisa Petrides (2003). Sumberdaya internal kepemimpinan, dapat mengancam retensi pengetahuan khususnya pergantian pada tingkat manajer atau penyelia senior. Pergantian posisi penting ini akan menghambat penggunaan data yang konsisten, mengurangi emosi berbagi atau transfer pengetahuan dalam tahapan sosialisasi, mengurangi efektifitas konversi human knowledge menjadi tipe tipe pengetahuan yang lain, seperti structured knowledge. Penelitian Irvan et.all (2012) mengidentifikasi sumberdaya kepemimpinan untuk mempengaruhi rantai kegiatan yang penting bagi core business. Sehingga pemimpin dapat melakukan retensi modal pengetahuan seiring dengan mobilisasi sumberdaya mendukung rantai kegiatan di perusahaan. Pembahasan fungsi kepemimpinan untuk mendukung retensi modal pengetahuan di fungsi fungsi utama bagi core business perusahaan menyangkut kepiawaian menjalan otoritas, mempengaruhi prioritas, perencanaan, pengembangan dan eksekusi tugas orang per orang di perusahaan. Kapasitas bertindak karyawan perusahaan dalam koridor visi jangka panjang dan strategi perusahaan menurut Chawla dan Joshi (2011), akan mendorong proses transfer pengetahuan dan pengembangan jaringan keahlian di dalam dan di luar perusahaan. Masalah sumberdaya kepemimpinan dan pengelolaan modal pengetahuan di perusahaan juga direkomendasikan oleh Supriyanta (2014) untuk pengelolaan di dunia pendidikan. Disebutkan, untuk mengelola pengetahuan, berbagi informasi dan sosialisasi direkomendasikan oleh Supriyanta seiring dengan hak dan kewajiban pengikut (followers) dan pemimpin (leader) di perusahaan. Mengelola sumberdaya manusia sebagai sumber pengetahuan, harus dilakukan seiring dengan menjalankan rutinitas dan prioritas perusahaan, kemampuan pemimpin mempengaruhi dan memotivasi karyawan menggunakan data dan informasi terbaru untuk kepentingan perusahaan dan bagi pengembangan human knowledge karyawan yang bersangkutan. Lebih dari itu, intensitas penggunaan data dan informasi terbaru bagi karyawan saat kini, sangat dipengaruhi teknologi informasi dan komunikasi. Oleh karena itu, peranan sumberdaya perusahaan seperti kepemimpinan dan retensi modal 
pengetahuan di era digital dapat diargumentasikan makin kritikal, seperti : memimpinan perkembangan e-transaksi dan data managemen, memimpin pembuatan keputusan yang beranjak dari kebaruan dan kebenaran data, e-komunikasi dari dan untuk multipemangku kepentingan (Blau dan Presser.2013)

Disebutkan Petrides (2003), Wamundila (2001), Irvan (2002), bahwa inefektif managemen teknologi informasi, juga merupakan sumberdaya internal perusahaan yang menghambat retensi sumberdaya pengetahuan perusahaan. Paling sering ditemui di perusahaan adalah minimnya referensi, akses, prosedur, panduan kerja, updated informasi, mengenai pelayanan dan operasi bisnis yang disuport oleh teknologi informasi. Dengan demikian efektivitas teknologi dalam mendukung operasi usaha sangat tergantung kepada keterandalan dari hardware dan software teknologi semata; semantara retensi modal pengetahuan perusahaan yang telah menggunakan teknologi dalam proses bisnis nya, karyawan IT juga memiliki pengetahuan tasit dan eksplisit berikut pengetahuan struktural di bagian IT di perusahaan. Oleh karena itu inefektif managemen teknologi informasi di perusahaan dapat dijelaskan dari minimnya retensi modal pengetahuan perusahaan yang melekat pada karyawan dan divisi IT. Sehingga komunikasi dan pembuatan keputusan di perusahaan akan terganggu ketika terjadi mal praktek di keahlian IT. Tipe pekerjaan atau proyek jangka pendek, yang kurang relevan dengan prioritas perusahan, juga mendorong inefektif management informasi untuk menjaga modal modal pengetahuan perusahaan. Utamanya, ketika proyek proyek tersebut tidak terkelola sistem teknologi penyimpanan dan pemanggilannya, sehingga loope komunikasi, transfer data dan informasi terbatas di sebagian unit perusahaan saja, dan tidak menjadi bagian dari akumulasi modal pengetahuan perusahaan yang dapat digunakan untuk pekerjaan selanjutnya. Hal ini juga terjadi di dunia pendidikan, sebagai lembaga yang mengedepankan teknologi pembelajaran. Kajian Ranjan dan Khalil (2007), disebutkan bahwa pengelolaan lembaga pendidikan salah satu upaya yang penting adalah interaksi manusia di lembaga pendidikan, mengintegrasi berbagai sumberdaya internal perusahaan, dengan aplikasi teknologi informasi,melalui proses administrasi akademik untuk mendukung belajar mengajar. Inefektif manajemen teknologi informasi, sebagai sumberdaya internal untuk mengelola retensi modal pengetahuan perusahaan, dengan demikian justru tidak terjadi ketika integrasi teknologi dan transfer pengetahuan tidak sanggup untuk mengelola interaksi berbagai pihak. Justru sebaliknya seringkali berbagai interaksi terhambat karena terlalu tergantung dengan keberadaan teknologi. Hal ini menunjukkan kekurangefektifan manajemen teknologi bagi upaya transfer pengetahuan dan retensi modal pengetahuan perusahaan. Kajian pengelolaan pengetahuan dan pengintegrasian teknologi informasi di dunia pendidikan juga disinggung oleh Petrides dan Nodine (2003). Pengelolaan manajemen pengetahuan, termasuk retensi modal pengetahuan, utamanya adalah mengelola interaksi pengajar dan staf akademik, interaksi antara aktivitas akademik dan web-based teknologi informasi untuk mengintegrasikan antara data kuantitatif dari mahasiswa dan kegiatan kelas dengan area keuangan, akutansi, dan proses-porses pendaftaran. Upaya retensi modal pengetahuan, sebagaimana dikatakan Petrides menekankan kajian proses kegiatan rutin operasional melalui teknologi seiring dengan pengembangan human knowledge karyawan 
dan staf pengajar di lembaga pendidikan. Beberapa sumberdaya internal perusahaan yang dapat mengancam pengelolaan human knowledge dan integrasi teknologinya, antara lain : keandalan pengetahuan karyawan yang melekat pada tugas mengelola teknologi informasi. Data yang tidak kompatibel dengan perkembangan piranti lunak, teknologi yang tidak terintegrasi, data yang tidak terpercaya validitasnya juga merupakan hambatan retensi modal pengetahuan. Sehingga tahapan tahapan dalam retensi modal pengetahuan perusahaan , sebagaimana disebutkan Arif (2012) untuk membentuk proses sosialisasi dan internalisasi pengetahuan kolektif terkendala karena manajemen teknologi. Misalnya piranti lunak yang tidak kompatibel dengan proses proses di lembaga pendidikan, disebutkan oleh Petrides, membuka peluang bagi tenaga akademik dan staf administrasi menyerahkan pengelolaan data kepada pihak pihak "ahli" dari luar atau pihak yang hanya memiliki keandalan teknis semata. Dengan demikian "ahli" tersebut tidak mencukupi kapasitasnya mengintegrasikan data dan informasi yang tersebar menjadi inputan, diskursus dan rekomendasi solusi untuk pembuatan keputusan atau pembaruan proses proses kerja di perusahaan. Termasuk ancaman bagi retensi modal pengetahuan perusahaan,menurut Petrides, yaitu pengelolaan data dan piranti lunak yang kadang karena satu hal terjadi manipulasi data. Meskipun fungsi data ada yang beranggapan bersifat minor, namun manipulasi data, meskipun kecil mengakibatkan distrust terhadap penggunaan data pada jangka panjang. Pada gilirannya akan membuka peluang pembuatan keputusan berdasarkan kebiasaan, tidak senyata dalam memenuhi kebutuhan multipemangku kepentingan perusahaan. Tentunya hal ini akan mempengaruhi proses tahapan retensi modal pengetahuan perusahaan, yang berakibat, hilang pengetahuan dan pembuatan keputusan di perusahaan tidak efektif.

Berdasarkan pembahasan pengenai sumberdaya internal perusahaan yang mengancam pengelolaan retensi modal pengetahuan, dapat disimpulkan pentingnya masalah staffing, leadership dan technology integrasion untuk mengelola retensi pengetahuan. Menjalankan tahapan pengelolaan retensi modal pengetahuan perusahan adalah mengelola pengetahuan yang melekat pada human menjadi modal pengetahuan bagi pengembangan usaha dan jasa sebuah perusahaan. Efektivitas pembuatan keputusan dan peningkatan kapasitas organisasi untuk berkembang dengan demikian terkait dengan bagaimana mengintegrasikan teknologi dalam pengambilan keputusan yang dikelola berdasarkan upaya pemerolehan pengetahuan, konversi pengetahuan ke dalam aktivititas individu dan kelompok. Demikian pula pembuatan keputusan untuk pengembangan kapasitas perusahaan memerlukan penyimpanan pengetahuan perusahaan dengan memperhatikan arti penting sumberdaya internal perusahaan, seperti proses recruit dan staffing, pemilihan proyek dan tipe pekerjaan, memperhatikan prioritas tugas yang relevan terhadap misi dan visi perusahaan, memperhatikan kapasitas kepemimpinan yang berorientasi kuat kepada kualitas data dan informasi.

\section{KESIMPULAN}

Penelitian ini membahas secara analitis deskriptis kajian kepustakaan mengenai pentahapan retensi modal pengetahuan, tipe tipe pengetahuan dan sumberdaya internal perusahan untuk mengelola retensi pengetahuan perusahaan. Retensi modal pengetanhuan 
perusahaan adalah mencegah hilangnya pengetahuan dan kapasitas pembuatan keputusan di perusahaan. Kesadaran akan arti penting pengetahuan sebagai aset perusahaan memerlukan pengelolaan tipe-tipe pengetahuan yang penting: pengetahuan yang melekat karyawan, mengetahuan relasional sosial di perusahaan, pengetahuan kultual menyangkut nilai nilai perusahaan dan pengetahuan organisasionial yang terstruktur untuk mendukung operasional bisnis. Berbagai tipe pengetahuan dikelola dalam tahapan retensi modal pengetahuan perusahaan dengan mempertimbangkan asesmen dan pemerolehan atau akuisisi pengetahuan tasit dan eksplisit, baik dalam bentuk pelatihan, pembetukan jaringan keahlian di dalam dan di luar perusahaan, dan menjalanka review atas pekerjaan dengan komunikasi dari data senyata. Transfer pengetahuan, berdasakan kemampuan perusahaan menyimpan dan memanggil pengetahuan, diperlukan seiring dengan ancaman sumberdaya internal perusahaan terhadap upaya retensi modal pengetahuan perusahaan, seperti: turnover, misstaffing, misrekruitmen, kepemimpinan yang lemah, dan proses pengelolaan bisnis yang tidak sejalan dengan kemajuan teknologi dan visi organisasi, dan kualitas data yang tidak senyata untuk memenuhi multi kebutuhan dari pemangku kepentingan. Untuk mengelola transfer pengetahuan antara lain diperlukan upaya mengintegrasikan antara sumberdaya manusia, proses di perusahaan dan manajemen teknologi, termassuk di dalamnya : pentingnya suksesi, jaringan komunitas, proses interaksi untuk membangun relasi emosional yang memudahkan berbagi pengetahuan, kepemimpinan yang mengedepankan pengelolaan data, informasi dan pengembangan pengetahuan. Aspek pengintegrasian teknologi yang mendukung pembuatan keputusan berbasis data dan kepemimpinan. Asesmen posisi kritikal di perusahaan dan modal pengetahuan yang melekat dan kemungkinan hilang ketika yang bersangkutan mundur dari perusahaan, kebaruan pengetahuan eksplisit, mendorong alur pengetahuan yang berbasis kemudahan akses dan berbagi pengalaman, maupun sumberdaya internal perusahaan yang pendukung kemampuan perusahaan meraih data dan informasi dari luar perusahaan untuk kepentingan transfer pengetahuan di internal perusahaan.

\section{DAFTAR PUSTAKA}

Arif, M et al. (2012) Assessing Knowledge Retention in Construction Consultancies: Cases from the UAE, Australian Journal of Construction Economics and Building, 12 (2) 5571

Asderaki, Foteini dan Joanna Samul. (2015) The Acquisition of Knowledge in Public Organizations : the Perspective of Employees. International Journal of Contemporary Management, 14 (2),22-32.

Blankenship, L. et. all., (2007) Developing a Knowledge Retention Strategy Now Saves Valuable Organizational Resources Later. Water Environtment Federation. Vienna. 2007

Blau, Ina., et.all. e-leadership of School Principals: Increasing Schools Effectiveness by a School Data 
Management System. British Journal od Education Technology. Vol 4.No 6.1000-1011

Chawla, Deepak dan Himansu Joshi. (2011) Impact od Knowledge Management on Learning Organization Practices in India. An Exploratory Analysis. The Learning Organization. Vol 18. No 6.501-516

DeLong, David W. (2004) , Lost of Knowledge: Confrontingthe Threat of an Aging Workforce.Oxford University Press.

Denner, Lize dan Diaz, Tricia. Knowledge Management in the Public Sector: An Online Presence as A Tool for Capture and Sharing. ECLAC. UN.2011

Farrukh, Muhammad and Abdul Waheed. (2015). Learning Organizational and Competitive Advantage: An Integrated Approach. Journal of Asian Business Strategy, 5(4), 7379.

Haula, Johanna. (2011) International Academic Knowledge Creation and ba. A case study from Findlan. Knowlede Management Research and Practice. 9.4-16

Irsan, Muhammad, Wenny Handiani Wiranata, Agustian Budi Prasetya. (2012) . Assesment of Knowledge Retention in PT. XXX (A Case Of
Catering Services Industry

Company). Laporan Penelitian

Consulting Project (Master Thesis). Universitas Bina Nusantara.

Lim, Tong Ming., et.all. A Study of the Knowledge Implementation Strategy and Its Influence on the Knowledge Sharing Attitudes among Knowledge Workers and Individual Job Performance. Journal of Economics and Behavioral Studies. Vol.5 No.12894-904

Nistor, Nicolae, et.all.(2015). Sense of Community in Academic Communities of Practice: Predictors and Effects. High Educ. 69: 257273

Nonaka, Ikujiro, et. all., Emergence of "Ba" in Knowledge Emergece: Social, Technical, and Evolutionary Dimensions of Knowledge Creation. New York. Oxford University Press, Inc. 2001. Ch. 3, pp.2-29

Petrides,Liza dan Thad Nodine. (2003) Knowledge Managementin Education: Defining the Lanscape. . Institute for the Study of Knowledge Management in Education.

Ranjan, Jayanthi dan Saani Khalil. (2007). Aplication of Knowledge Management in Management Education: A Conceptual Framework. Journal of Theoritical 
Retensi Modal Pengetahuan dan Sumberdaya

pISSN : 1412-629X

Internal Perusahaan

and Applied Information

technology. Pp 15-25

Supriyanta. (2014). Knowledge Management untuk Peningkatan Pelayanan Akademik pada Perguruan Tinggi. Bianglala Informatika. Vol II.Maret.

Wamundila (2011). Enhancing knowledge retention in higher education: A case of the University of Zambia. Journal of Information Management, Vol 13, No 1. 